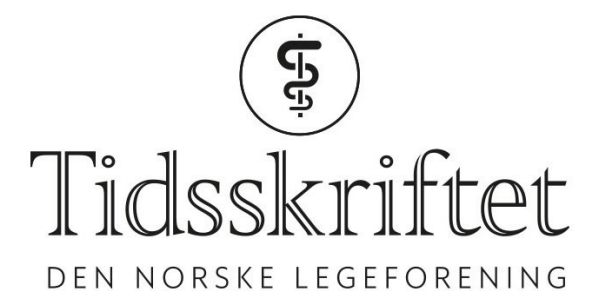

DEN NORSKE LEGEFORENING

\title{
MS-behandlingen er ikke så effektiv
}

DEBATT

\section{SIGBJØRN OLAV ROGNE}

E-post: sigrogne@online.no

Sigbjørn Olav Rogne er dr.med. og spesialist i fordøyelsessykdommer og i geriatri.

Forfatteren har fylt ut ICMJE-skjemaet og oppgir følgende interessekonflikter: Han har multippel sklerose og fikk cellegiftbehandling med autolog stamcellestøtte i januar 2015 ved Careggi universitetssykehus i Firenze, med god effekt.

Bremsemedisinene er ikke så effektive som det gis inntrykk av. Legemiddelfirmaer kjøper innflytelse i behandlingen av multippel sklerose.

Da Beslutningsforum høsten 2019 vedtok begrensninger i bruken av såkalte bremsemedisiner mot multippel sklerose (MS), fikk de sterk kritikk fra industri, nevrologer og MS-forbundet (1-3). Multippel sklerose er en autoimmun sykdom og bremsemedisinene har effekt ved å hemme immunforsvaret. Jeg vil hevde at bremsemedisinene ikke er så effektive som industrien antyder, og at nevrologer påvirkes av legemiddelfirmaer.

Ett eksempel på kjøp av innflytelse ser vi i USA. Bremsemedisiner og andre medisiner ble flere ganger dyrere enn $\mathrm{i}$ andre land etter at Kongressen vedtok loven Medicare Prescription Drug Bill i $2003(4,5)$. Loven forbød Medicare (offentlig helseforsikringssystem for eldre $>65$ år og uføre) å forhandle pris med legemiddelfirmaer på legemidler forskrevet av lege (4).

Kongressrepresentant Billy Tauzin mottok store pengebeløp fra PhRMA (Legemiddelindustrien) og fikk igjennom lovforslaget. Senere ble han leder av PhRMA (6, 7).

Informasjon om honorarer fra legemiddelfirmaer til norske leger er ikke fritt tilgjengelig, men opplysninger formidlet gjennom Dagens Medisin viser at flere nevrologer mottok større beløp i $2017(7,8)$. Pasientforeninger som MS-forbundet mottar også midler og materiell fra legemiddelfirmaer (7).

\section{Legemiddelfirmaenes helsetjeneste}

Beslutningsforum vedtok at sykehusene ikke skal bruke bremsemedisinen okrelizumab, og at sykehusene kan bruke rituksimab som bremsemedisin utenfor godkjent indikasjon (9). Okrelizumab og rituksimab er nesten identiske, og sannsynligvis valgte legemiddelfirmaet å ikke få rituksimab godkjent som MS-medisin fordi patentet løp ut i 2015 (10). Ett års okrelizumab-behandling koster ca. $28 \mathrm{o}$ ooo kroner, rituksimab er 14 ganger rimeligere (10, 11).

Jeg vil hevde at bremsemedisinene ikke er så effektive som industrien antyder, og at nevrologer påvirkes av legemiddelfirmaer

Legemiddelet Campath (alemtuzumab) mot kronisk lymfatisk leukemi ble avregistrert i 
2012, kanskje fordi det var mer kommersielt interessant som bremsemedisin (12)? Da det ble godkjent som bremsemedisin i 2013, ble prisen 40 ganger så høy som den var. Første behandling koster ca. 490 ooo $\mathrm{kr}$ (13). Psoriasismedisinen dimetylfumarat ble godkjent som bremsemedisin i 2013, prisen ble så tidoblet til ca. 150 ooo kroner årlig (14). Og da leddgiktmedisinen teriflunomid ble godkjent som bremsemedisin det samme året, ble prisen tyvedoblet til ca. 110 ooo kroner årlig (15).

\section{Tvilsom effekt}

Studier viser at bremsemedisiner har begrenset effekt, og mange MS-pasienter opplever etter hvert at sykdommen går sin skjeve gang (16-19). Sykdommen fører til tap av mange gode leveår, og gjennomsnittlig levetid er redusert med 6-14 år (20-22).

Studier på cellegiftbehandling med stamcellestøtte (HSCT-behandling) ved multippel sklerose viser klart bedre resultat og at behandlingen kan stanse sykdommen $(17,18)$. Denne behandlingen har forholdsvis lav risiko, og dødeligheten er $<0,3 \%$ (17). HSCT-behandling koster ca. 480 ooo kroner, hovedsakelig pga. isolatopphold i sykehus (23). Legemiddelfirmaer skaper inntrykk av at bremsemedisinene er så effektive at HSCTbehandling er overflødig, for farlig og bare virker for dem med hissigst sykdomsaktivitet, dette til tross for at det ikke er utført studier på HSCT-behandling hos MS-pasienter med vanlig sykdomsaktivitet $(16,19,24)$.

\section{Legemiddelfirmaer har skapt misoppfatninger}

Følgende misoppfatninger hos pasienter, politikere og beslutningstakere skyldes etter mitt syn legemiddelindustriens kjøp av innflytelse:

Multippel sklerose er ikke en sykdom en dør av, men med (20-22). Det oppnås nå god sykdomskontroll med bremsemedisiner $(16,18,19,22)$. MR-undersøkelse av hjernen kan avkrefte betennelsesaktivitet (MR har begrenset oppløsning og kan bare påvise større grader av betennelsesaktivitet) (25-27). HSCT-behandling er overflødig pga.

bremsemedisinene og er for farlig (17-19). HSCT-behandling virker bare på MS-pasientene med hissigst sykdomsaktivitet (24).

\section{LITTERATUR:}

1. Moe L. Nevrologileder: - Legene instrueres. Dagens Medisin 23.12.2019.

https://www.dagensmedisin.no/artikler/2019/12/23/nevrologileder-legene-instrueres/ Lest 14.2.2020.

2. Bekkemellem K. MS-pasienter taper i kampen om en likeverdig helsetjeneste. Dagens Medisin 9.12.2019.

https://www.dagensmedisin.no/blogger/karita-bekkemellem/2019/12/o9/ms-pasienter-taper-i-kampenom-en-likeverdig-helsetjeneste/ Lest 14.2.2020.

3. Moe L. MS-forbundet: Vi har kommet i en vanskelig situasjon med Beslutningsforum. Dagens Medisin 23.12.2019.

https://www.dagensmedisin.no/artikler/2019/12/23/ms-forbundet-vi-har-kommet-i-en-vanskelig-situasj on-med-beslutningsforum/ Lest 14.2.2020.

4. Potter W, Penniman N. The Lobbyist Who Made You Pay More at the Drugstore. Moyers. https://billmoyers.com/story/the-man-who-made-you-pay-more-at-the-drugstore/ Lest 14.2.2020.

5. Hartung DM, Bourdette DN, Ahmed SM et al. The cost of multiple sclerosis drugs in the US and the pharmaceutical industry: Too big to fail? Neurology 2015; 84: 2185-92. [PubMed][CrossRef]

6. McGreal C. How big pharma's money - and its politicians - feed the US opioid crisis. The Guardian 19.10.2017.

https://www.theguardian.com/us-news/2017/oct/19/big-pharma-money-lobbying-us-opioid-crisis Lest 14.2.2020.

7. Parker L, Williams J, Bero L. Ethical drug marketing criteria for the 21st century. BMJ 2018; 361: k1809. 
8. Engen $\emptyset \mathrm{B}$. Etterlyser full åpenhet om honorarer. Dagens Medisin 11.10.2018. https://www.dagensmedisin.no/artikler/2018/10/11/etterlyser-full-apenhet-om-honorarer/ Lest 14.2.2020.

9. Slørdahl S. Sant og usant om MS-medisiner. Dagens Medisin 13.12.2019.

https://www.dagensmedisin.no/artikler/2019/12/13/sant-og-usant-om-ms-medisiner/ Lest 14.2.2020.

10. Raknes G. Utenfor etiketten? Tidsskr Nor Legeforen 2018; 138. doi: 10.4045/tidsskr.18.0522.

[PubMed][CrossRef]

11. Rogne S. Shall the pharmaceutical companies decide which trials to perform? Tidsskr Nor Legeforen 2017; 137: 183. [PubMed][CrossRef]

12. Alemtuzumab for multiple sclerosis. Lancet 2012;380: 1792. [CrossRef]

13. Aaserud S. Norsk stjerneforsker går i strupen på legemiddelindustrien:- Det handler om profitt og grådighet. TV2 4.9.2016. https://www.tv2.no/a/8562911/ Lest 14.2.2020.

14. Toumi M, Jadot G. Economic impact of new active substance status on EU payers' budgets: example of dimethyl fumarate (Tecfidera(®)) for multiple sclerosis. J Mark Access Health Policy 2014; 2: 23932. [PubMed][CrossRef]

15. Millar JA. The cost of teriflunomide in the treatment of relapsing-remitting multiple sclerosis. N Z Med J 2019; 132:36-41. [PubMed]

16. Rotstein DL, Healy BC, Malik MT et al. Evaluation of no evidence of disease activity in a 7-year longitudinal multiple sclerosis cohort. JAMA Neurol 2015; 72: 152-8. [PubMed][CrossRef]

17. Muraro PA, Martin R, Mancardi GL et al. Autologous haematopoietic stem cell transplantation for treatment of multiple sclerosis. Nat Rev Neurol 2017; 13:391-405. [PubMed][CrossRef]

18. Burt RK, Balabanov R, Burman J et al. Effect of nonmyeloablative hematopoietic stem cell transplantation vs continued disease-modifying therapy on disease progression in patients with relapsing-remitting multiple sclerosis. JAMA 2019;321: 165-74. [PubMed][CrossRef]

19. Decisional dilemmas in discontinuing prolonged disease-modifying treatment for multiple sclerosis. https://effectivehealthcare.ahrq.gov/sites/default/files/pdf/multiple-sclerosis_research.pdf Rockville: Agency for Healthcare Research and Quality, 2015.

20. Kingwell E, Leray E, Zhu F et al. Multiple sclerosis: effect of beta interferon treatment on survival. Brain 2019; 142: 1324-33. [PubMed][CrossRef]

21. Scalfari A, Knappertz V, Cutter G et al. Mortality in patients with multiple sclerosis. Neurology 2013; 81:184-92. [PubMed][CrossRef]

22. Coles A. Multiple sclerosis. Pract Neurol 2009; 9: 118-26. [PubMed][CrossRef]

23. Giske L, Lauvrak V, Stoinska-Schneider A et al. Autolog hematopoietisk stamcelletransplantasjon ved multippel sklerose. Rapport nr. 23-2015. Oslo: Kunnskapssenteret, 2015.

https://nyemetoder.no/Documents/Rapporter/Rapport_2015_23_MS_Stamceller.pdf Lest 14.2.2020.

24. Rogne S. Unethical for neurologists not to offer patients with multiple sclerosis chemotherapy with autologous stem cell support. Tidsskr Nor Legeforen 2014; 134: 1931-2. [PubMed][CrossRef]

25. Hedlund F. Multipel skleros en nytolkad sjukdom. Karolinska Institutet.

https://ki.se/forskning/multipel-skleros-en-nytolkad-sjukdom Lest 14.2.2020.

26. Piehl F. Setting the scene: the relevance of conventional CSF and imaging biomarkers in MS. Ectrims Online Library.

https://onlinelibrary.ectrims-congress.eu/ectrims/2019/stockholm/279401/fredrik.piehl.setting.the.sce ne.the.relevance.of.conventional.csf.and.imaging.html Lest 14.2.2020.

27. Sicotte NL, Voskuhl RR, Bouvier S et al. Comparison of multiple sclerosis lesions at 1.5 and 3.0 Tesla. Invest Radiol 2003; 38: 423-7. [PubMed][CrossRef] 
(ㅇ) Tidsskrift for Den norske legeforening 2020. Lastet ned fra tidsskriftet.no 